\title{
Energetics of syntrophic ethanol oxidation in defined chemostat cocultures
}

\section{Energy sharing in biomass production}

\author{
H.-J. Seitz ${ }^{1}$, B. Schink ${ }^{2}$, N. Pfennig ${ }^{1}$, and R. Conrad ${ }^{1}$ \\ 1 Fakultät für Biologie, Universität Konstanz, P.O. Box 5560, W-7750 Konstanz, Federal Republic of Germany \\ ${ }^{2}$ Lehrstuhl Mikrobiologie I, Universität Tübingen, W-7400 Tübingen, Federal Republic of Germany
}

\begin{abstract}
The ethanol-oxidizing, proton-reducing Pelobacter acetylenicus was grown in chemostat cocultures with either Acetobacterium woodii, Methanobacterium bryantii, or Desulfovibrio desulfuricans. $\mathrm{Y}_{\max }$ and $\mathrm{m}_{\mathrm{e}}$ were determined from the total molar growth yields determined at growth (dilution) rates between 0.02 and $0.14 \mathrm{~h}^{-1}$. The individual growth yields of the partner organisms were determined from their numbers and cellular mass in the chemostat cocultures. The Gibbs free energy $(\Delta \mathrm{G}=-16.3 \mathrm{~kJ} / \mathrm{mol}$ ethanol) available to $P$. acetylenicus as well as its $Y_{\max }(1.7-2.2 \mathrm{~g} / \mathrm{mol}$ ethanol) were almost constant in the different cocultures. $P$. acetylenicus shared $44-67 \%$ of the total biomass produced, whereas it shared only 19,23 , and $37 \%$ of the total Gibbs free energy $(\Delta G)$ available from ethanol oxidation coupled to sulfate reduction, methanogenesis, and homoacetogenesis, respectively. The residual $63-81 \%$ of the total available $\Delta \mathrm{G}$ were shared by the $\mathrm{H}_{2}$ oxidizers which exhibited $\mathrm{Y}_{\max }$ values being highest for $A$. woodii $(6.6 \mathrm{~g} / \mathrm{mol}$ acetate $)>D$. desulfuricans $(3.8 \mathrm{~g} / \mathrm{mol}$ sulfide $)$ $>$ M. bryantii $\left(2.2 \mathrm{~g} / \mathrm{mol} \mathrm{CH}_{4}\right)$. The results are discussed with respect to ATP generation and coupling of catabolism with cell production.
\end{abstract}

Key words: Pelobacter acetylenicus - Acetobacterium woodii - Methanobacterium bryantii - Desulfovibrio desulfuricans - Growth yield - Maintenance coefficient - Gibbs free energy $-Y_{\text {ATP }}$

Syntrophic oxidation of ethanol to acetate is accomplished in cocultures of ethanol-fermenting $\mathrm{H}_{2}$-producing and $\mathrm{H}_{2}$-consuming bacteria. The energy available from ethanol oxidation depends on the type of $\mathrm{H}_{2}$ oxidizing species and on the terminal electron acceptor used; e.g. whether $\mathrm{H}_{2}$ is oxidized by homoacetogenic, methanogenic, or sulfate-reducing bacteria $\left(\Delta \mathrm{G}^{0 \prime}\right.$ per reaction):

$$
\begin{aligned}
& 2 \mathrm{CH}_{3} \mathrm{CH}_{2} \mathrm{OH}+2 \mathrm{HCO}_{3}^{-} \rightarrow 3 \mathrm{CH}_{3} \mathrm{COO}^{-}+3 \mathrm{H}^{+} \\
& +2 \mathrm{H}_{2} \mathrm{O} ;(-85.6 \mathrm{~kJ}) \\
& 2 \mathrm{CH}_{3} \mathrm{CH}_{2} \mathrm{OH}+\mathrm{HCO}_{3}^{-} \rightarrow 2 \mathrm{CH}_{3} \mathrm{COO}^{-}+2 \mathrm{H}^{+} \\
& +\mathrm{CH}_{4}+\mathrm{H}_{2} \mathrm{O} ;(-116.8 \mathrm{~kJ}) \\
& 2 \mathrm{CH}_{3} \mathrm{CH}_{2} \mathrm{OH}+\mathrm{SO}_{4}^{2-} \rightarrow 2 \mathrm{CH}_{3} \mathrm{COO}^{-}+\mathrm{HS}^{-}+\mathrm{H}^{+} \\
& +2 \mathrm{H}_{2} \mathrm{O} ;(-133.2 \mathrm{~kJ}) .
\end{aligned}
$$

The energy of these reactions must be shared by three partial reactions, twice the oxidation of $1 \mathrm{~mol}$ of ethanol and once the oxidation of the resulting $4 \mathrm{~mol}$ of $\mathrm{H}_{2}$ to form either acetate, $\mathrm{CH}_{4}$, or $\mathrm{HS}^{-}$. The reversible synthesis of 1 ATP requires under the conditions in a living cell about $+50 \mathrm{~kJ} \mathrm{~mol}^{-1}$ (Thauer et al. 1977). As part of the energy budget of a cell is always lost as heat, about $+70 \mathrm{~kJ} \mathrm{~mol}^{-1}$ is required for irreversible ATP biosynthesis (Schink 1990). Hence, syntrophic degradation of ethanol may yield fractions of one ATP per partial reaction. So far it is unknown how the energy is really shared among syntrophic partners. However, this share of energy must be sufficient to sustain cell integrity and drive biomass production for growth of each syntrophic partner.

In an accompanying paper (Seitz et al. 1990a), we determined the Gibbs free energy available to both ethanol oxidation and $\mathrm{H}_{2}$ oxidation at steady state conditions in chemostat cocultures. Here, we determine the cell production rates and growth yields of each of the syntrophic partners during ethanol degradation in homoacetogenic, methanogenic, and sulfate-reducing chemostat cocultures.

\section{Materials and methods}

Organisms, cultivation, and analytical determinations

Pelobacter acetylenicus WoAcyl was grown in ethanol-limited chemostat cocultures with either Methanobacterium bryantii $\mathrm{MoH}$, Acetobacterium woodii NZva16, or Desulfovibrio desulfuricans Essex 


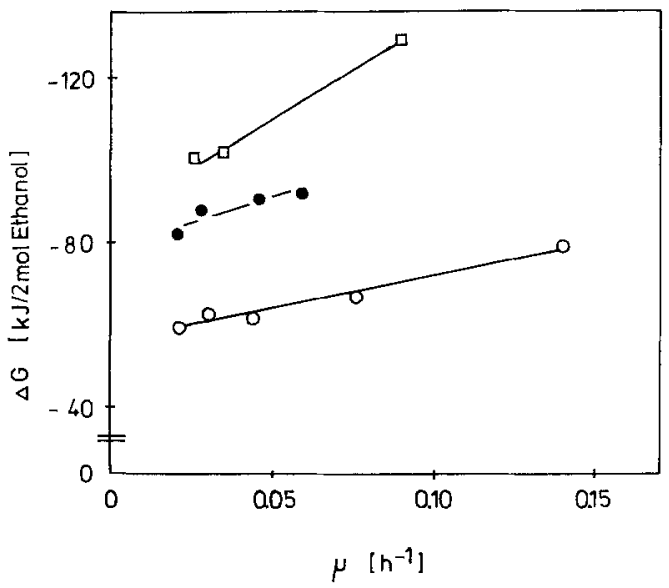

Fig. 1. Gibbs free energies $(\triangle G)$ of syntrophic ethanol oxidation determined in ethanol-limited chemostat cocultures of Pelobacter acetylenicus plus either Acetobacterium woodii (O), Methanobacterium bryantii ( $)$, or Desulfovibrio desulfuricans ( $\square$ ) as partner organisms

6 as $\mathrm{H}_{2}$-oxidizing syntrophic partner. The origin of bacterial strains, the cultivation techniques, and other analytical determinations are described in the accompanying paper (Seitz et al. 1990a).

\section{Growth yields}

Growth was followed by measuring the optical density $\left(\mathrm{OD}_{650}\right)$ at $650 \mathrm{~nm}$ and $1 \mathrm{~cm}$ light path in a spectrophotometer (Bausch \& Lomb, Rochester, NY, USA). Cell numbers were counted by phase contrast or fluorescence microscopy after fixation with $0.7 \%$ formaldehyde using a Helber countıng chamber. Bacterial dry mass was determined gravimetrically in samples $(800 \mathrm{ml})$ of pure bacterial cultures. The samples were gassed with $\mathrm{CO}_{2}$ to remove $\mathrm{H}_{2} \mathrm{~S}$, centrifuged and washed with $50 \mathrm{mM}$ ammonum acetate buffer (pH 6.0). The washed suspension was transferred into glass tubes and dried at $80^{\circ} \mathrm{C}$ to constant weight. Cell suspensions of $\mathrm{OD}_{550}=1.0$ contained per liter: $402 ; 338 ; 392 ; 400 \mathrm{mg}$ d.w. cells for $P$. acetylenicus, $A$. woodii, $M$. bryantii, $D$. desulfuricans, respectively. The corresponding cell number was $\left(\times 10^{8}\right.$ cells $\left./ \mathrm{ml}\right): 23.2 ; 8.4 ; 4.6$; 22.0. The corresponding specific cell mass $\left(x_{1}\right)$ was (pg d.w./cell): $0.17 ; 0.40 ; 0.85 ; 0.18$.

The dry mass $\left(\mathrm{X}_{1}\right)$ of each of the cocultured bacteria was calculated from the total cell mass $(X)$, the relative cell numbers $\left(N_{1}\right)$ in the culture and the specific cell masses $\left(x_{\mathrm{i}}\right)$ :

$\mathrm{X}_{1}=\mathrm{X} x_{1} \mathrm{~N}_{1} /\left(x_{1} \mathrm{~N}_{1}+x_{2} \mathrm{~N}_{2}\right)$

$\mathrm{X}=\mathrm{X}_{1}+\mathrm{X}_{2}$

$1=\mathrm{N}_{1}+\mathrm{N}_{2}$.

\section{Results}

The Gibbs free energies of ethanol conversion under steady state conditions in chemostat cocultures increased linearly with the growth rate, and were higher (more negative) with sulfate reducers $>$ methanogens $>$ homoacetogens (Fig. 1). The Gibbs free energies available under steady state conditions in the chemostat were in a range of -60 to $-128 \mathrm{~kJ}$ per $2 \mathrm{~mol}$ of ethanol as

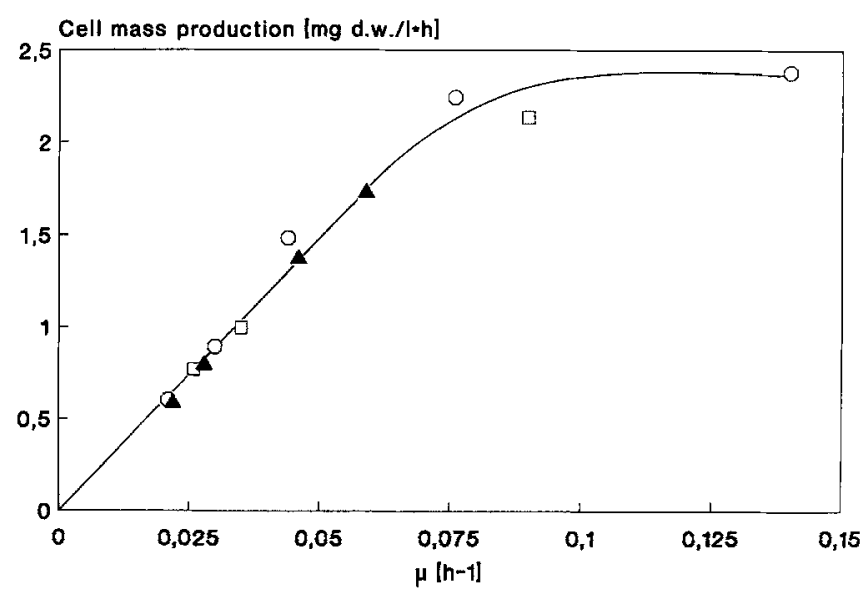

Fig. 2. Rates of total cell mass production in ethanol-limited chemostat cocultures of $P$. acetylenicus plus either $A$. woodii $(O)$, $M$. bryantii ( $\mathbf{\Lambda})$, or $D$. desulfuricans $(\square)$

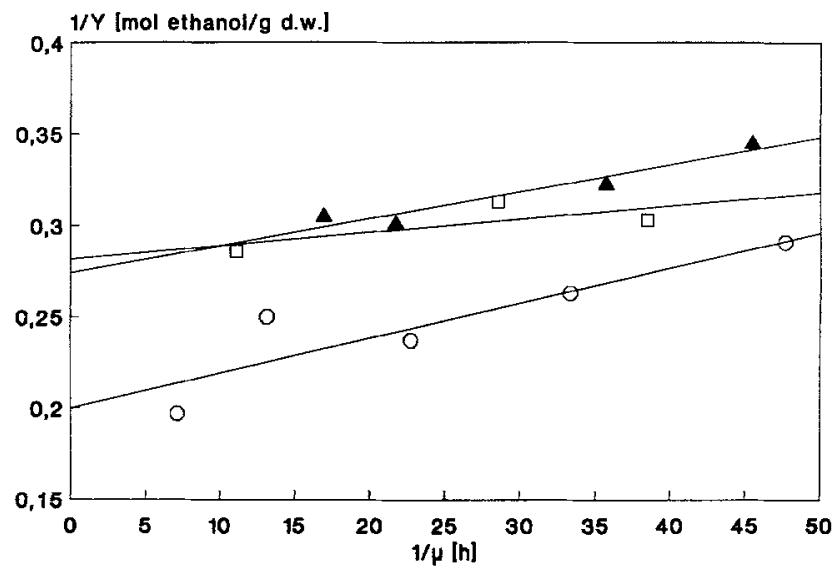

Fig. 3. Reciprocal plot of growth yields $(1 / Y)$ versus growth (dilution) rates $(1 / \mu)$ in ethanol-limited chemostat cocultures of $P$. acetlyenicus plus either $A$. woodii $(O), M$. bryantii $(\mathbf{\Lambda})$, or $D$. desulfuricans ( $\square$ )

compared to -86 to $-133 \mathrm{~kJ}$ per $2 \mathrm{~mol}$ of ethanol under standard conditions.

Rates of total cell mass production increased linearly with growth rates and were almost identical in the cocultures with homoacetogens, methanogens, and sulfate reducers (Fig. 2). Slight differences in cell production and slight differences in ethanol consumption resulted in only slight but significant differences in total molar growth yields (Y). As theoretically implied by the Pirt equation (Pirt 1965), $1 / \mathrm{Y}$ increased linearly with $1 / \mu$ (Fig. 3). The maximum growth yields $\left(\mathrm{Y}_{\max }\right)$ calculated from these plots resulted in higher values with the homoacetogenic Acetobacterium woodii than with the methanogenic Methanobacterium bryantii or the sulfatereducing Desulfovibrio desulfuricans as partner organisms (Table 1). The maintenance coefficients $\left(\mathrm{m}_{\mathrm{e}}\right)$ were higher with $A$. woodii $>M$. bryantii $>D$. desulfuricans (Table 1).

Growth yields of each syntrophic partner were determined individually via biomass. The cell shapes were sufficiently distinctive to separately count the cell titers 
Table 1. Maximum growth yields $\left(Y_{\max }\right)$ and maintenance coefficients $\left(m_{e}\right)$ of Pelobacter acetylenicus cocultured with different anaerobic $\mathrm{H}_{2}$ oxidizers on ethanol

\begin{tabular}{lll}
\hline $\begin{array}{l}\mathrm{H}_{2} \text {-oxidizing } \\
\text { partner }\end{array}$ & $\begin{array}{l}\mathrm{Y}_{\max } \\
{[\mathrm{g} / \mathrm{mol} \text { ethanol] }}\end{array}$ & $\begin{array}{l}m_{e} \\
{[\mathrm{mmol} \text { ethanol }} \\
\left.\mathrm{h}^{-1} \mathrm{~g}^{-1}\right]\end{array}$ \\
\hline $\begin{array}{l}\text { Acetobacterium woodii } \\
\text { Methanobacterium bryantii }\end{array}$ & 5.0 & 1.93 \\
Desulfovibrio desulfuricans & 3.6 & 1.22 \\
\end{tabular}

of $P$. acetylenicus and either $A$. woodii, $M$. bryantii, or $D$. desulfuricans in the cocultures (Fig. 4). The relative contribution of cells of the $\mathrm{H}_{2}$ producers and $\mathrm{H}_{2}$ oxidizers to the total cell number in the chemostat was independent of the growth rate, but changed with the type of coculture (Table 2). However, when these numbers were corrected for the cell mass of the individual species, the percentage contribution of $P$. acetylenicus to the total cell biomass was similar in the cocultures with the homoacetogens and the sulfate reducers, and was somewhat higher in cocultures with $M$. bryantii (Table 2).

The individual growth yields of the $\mathrm{H}_{2}$ producers and $\mathrm{H}_{2}$ consumers in the different cocultures were calculated from the relative amounts of their individual biomass and the total maximum growth yield (Table 3 ). The maximum growth yields of the $\mathrm{H}_{2}$-producing $P$. acetylenicus were similar in all three different cocultures. However, the $\mathrm{Y}_{\max }$ of the $\mathrm{H}_{2}$ oxidizers were highest for $A$. woodii $>D$. desulfuricans $>M$. bryantii (Table 3 ). A similar trend was observed for $\mathrm{Y}_{A \mathrm{G}}$, which was calculated from $Y_{\max }$ and the Gibbs free energy that was available to each of the syntrophic partners (Seitz et al. 1990a) assuming that the $A \mathrm{G}$ value extrapolated for a growth rate of $\mu=0.2 \mathrm{~h}^{-1}$ approximately represents the energy available for generation of $Y_{\max }$.

\section{Discussion}

Syntrophic partners must grow together sharing the energy available from substrate degradation and sharing a common growth yield. Our results show for the first time that the energy content of a syntrophic degradation reaction is not equally shared between the contributing partners. Since ethanol conversion to acetate plus either "homoacetate", methane, or sulfide involves three stoichiometric partial reactions, a sharing fo $67 \%$ of the $\mathrm{H}_{2}$ producing ethanol fermenter and $33 \%$ for the $\mathrm{H}_{2}$ oxidizer would be expected.

However, ethanol-fermenting Pelobacter acetylenicus shared only $19-37 \%$ of the available Gibbs free energy of ethanol oxidation, but formed $47-67 \%$ of the total biomass produced. The $\mathrm{H}_{2}$-oxidizing syntrophic partners, on the other hand, had a larger share of the available energy, but obtained a relatively smaller growth yield.

Sharing of substrate conversion energy and growth yields depended strongly on the type of $\mathrm{H}_{2}$-oxidizing reaction. The homoacetogenic Acetobacterium woodii
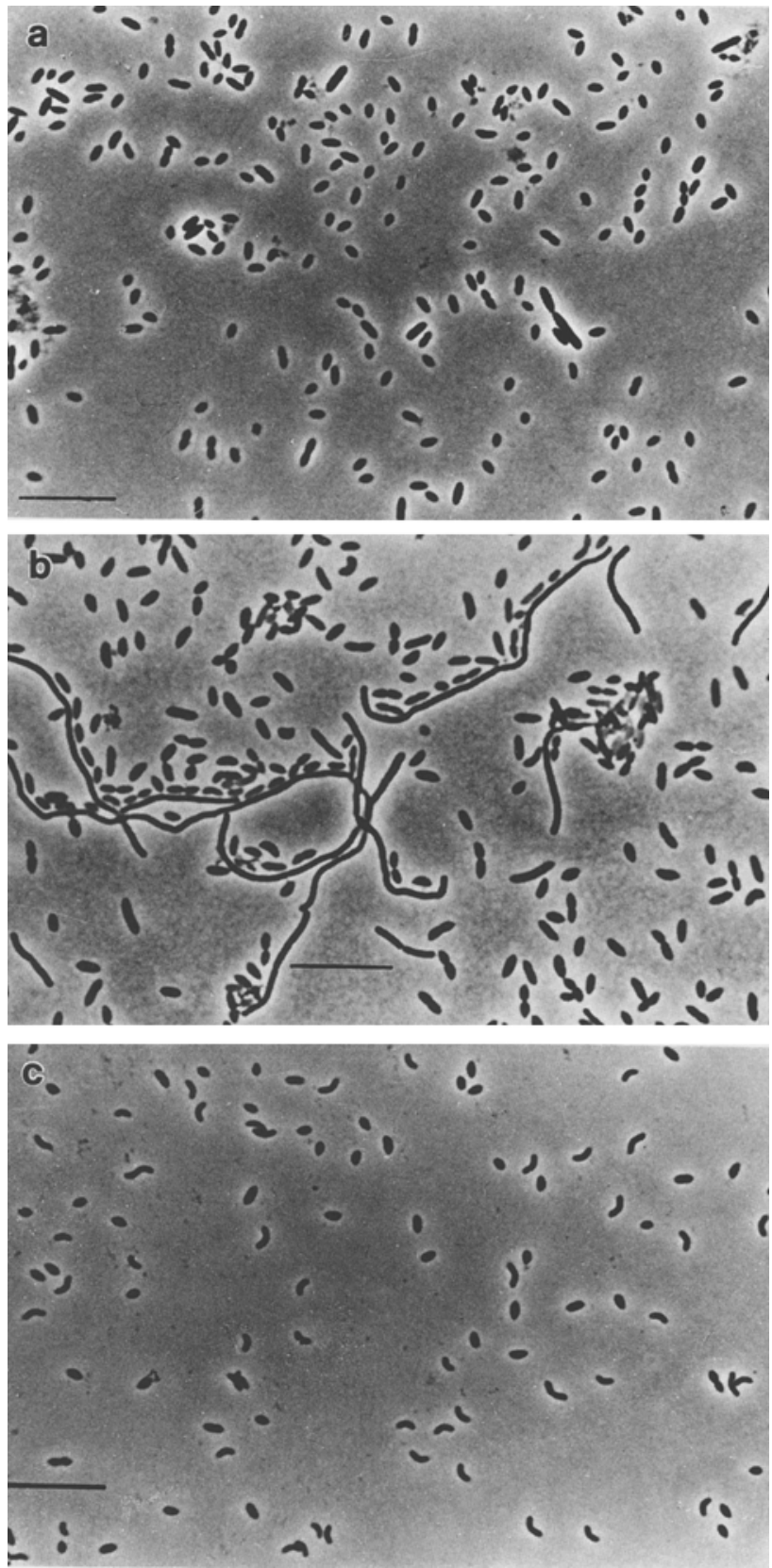

Fig. 4a-c. Phase-contrast photomicrographs of the bacteria in ethanol-limited chemostat cocultures of $P$. acetylenicus plus either A. woodii (a), M. bryantii (b), or D. desulfuricans (c). Bar $=10 \mu \mathrm{m}$

had the largest $\mathrm{Y}_{\max }$ sharing $63 \%$ of the available energy and $52 \%$ of the total growth yield. The methanogenic Methanobacterium bryantii, on the other hand, had the smallest $\mathrm{Y}_{\max }$ sharing $77 \%$ of the available energy and $33 \%$ of the total growth yield. The maintenance coefficients for syntrophic ethanol conversion were higher in homoacetogenic $>$ methanogenic $>$ sulfate-reducing cocultures.

The individual $\mathrm{Y}_{\max }$ of $A$. woodii, $M$. bryantii, and Desulfovibrio desulfuricans in syntrophic coculture with ethanol-fermenting $P$. acetylenicus are due to growth on $\mathrm{H}_{2}$ obtained by interspecies $\mathrm{H}_{2}$ transfer. The $\mathrm{Y}_{\max }$ determined for $A$. woodii $\left(6.6 \mathrm{~g} / 4 \mathrm{~mol} \mathrm{H}_{2}\right)$ and $M$ bryantii 
Table 2. Partitioning of cell titer and cell mass between $\mathrm{H}_{2}$-producing $P$. acetylenicus and different $\mathrm{H}_{2}$-oxidizing anaerobes in chemostat cocultures with ethanol ${ }^{\mathrm{a}}$

a Average values \pm SD from determinations at various dilution rates between 0.02 and $0.14 \mathrm{~h}^{-1}$

\begin{tabular}{llll}
\hline Coculture & $\begin{array}{l}\text { P. acetylenicus } \\
+ \text { A. woodii }\end{array}$ & $\begin{array}{l}\text { P. acetylenicus } \\
+ \text { M. bryantii }\end{array}$ & $\begin{array}{l}\text { P. acetylenicus } \\
+ \text { D. desulfuricans }\end{array}$ \\
\hline Titer $\left[10^{7}\right.$ cells ml $\left.{ }^{-1}\right]$ & $11 \pm 2$ & $12 \pm 1$ & $16 \pm 2$ \\
$\mathrm{H}_{2}$ producer [\%] & $65 \pm 3$ & $91 \pm 1$ & $48 \pm 6$ \\
$\mathrm{H}_{2}$ oxidizer [\%] & $35 \pm 3$ & $9 \pm 1$ & $52 \pm 6$ \\
\hline Total cell mass [mg 1 & & $28.6 \pm 1.4$ & $27.3 \pm 3.2$ \\
$\mathrm{H}_{2}$ producer [\%] & $27.7 \pm 6.3$ & 67 & 47 \\
$\mathrm{H}_{2}$ oxidizer [\%] & 44 & 33 & 53 \\
\hline
\end{tabular}

\begin{tabular}{|c|c|c|c|}
\hline Coculture & $\begin{array}{l}\text { P. acetylenicus } \\
+ \text { A. woodii }\end{array}$ & $\begin{array}{l}\text { P. acetylenicus } \\
+M . \text { bryantii }\end{array}$ & $\begin{array}{l}\text { P. acetylenicus } \\
+D \text {. desulfuricans }\end{array}$ \\
\hline \multicolumn{4}{|c|}{$-\Delta \mathrm{G}[\mathrm{kJ} / 2 \mathrm{~mol} \text { ethanol }]^{\mathrm{a}}$} \\
\hline $\mathrm{H}_{2}$ producer & $32.6(37 \%)$ & $32.6(23 \%)$ & $32.6(19 \%)$ \\
\hline $\mathrm{H}_{2}$ oxidizer & $54.8(63 \%)$ & $111.2(77 \%)$ & $136.0(81 \%)$ \\
\hline \multicolumn{4}{|c|}{$\mathrm{Y}_{\max }[\mathrm{g} / 2 \mathrm{~mol} \text { ethanol }]^{\mathrm{b}}$} \\
\hline $\mathrm{H}_{2}$ producer & $4.4(44 \%)$ & $4.4(67 \%)$ & $3.4(47 \%)$ \\
\hline $\mathrm{H}_{2}$ oxidizer & $5.6(56 \%)$ & $2.2(33 \%)$ & $3.8(53 \%)$ \\
\hline \multicolumn{4}{|l|}{$Y_{\Delta \mathrm{G}}[\mathrm{g} / 70 \mathrm{~kJ}]^{\mathrm{c}}$} \\
\hline $\mathrm{H}_{2}$ producer & 9.4 & 9.4 & 7.3 \\
\hline $\mathrm{H}_{2}$ oxidizer & 7.1 & 1.4 & 2.0 \\
\hline
\end{tabular}

Table 3. Sharing of available Gibbs free energies $(\Delta \mathrm{G})$ and maximum molar growth yields $\left(\mathrm{Y}_{\max }\right)$ between $\mathrm{H}_{2}$-producing $P$. acetylenicus and different $\mathrm{H}_{2}$-oxidizing anaerobes, and calculation of the individual $Y_{A G}$

a Calculated from the chemostat data derived from Fig. 4 (Seitz et a1. 1990a) extrapolated to $\mu=0.2 \mathrm{~h}^{-1}$

b Calculated from $Y_{\max }$ given in Table 1 and the percentage cell mass of $\mathrm{H}_{2}$ producers and oxidizers given in Table 2

${ }^{\circ} \mathrm{Y}_{\Delta \mathrm{G}}=70 \mathrm{Y}_{\mathrm{max}} /-\Delta \mathrm{G}$; normalized to an energy quantum of $70 \mathrm{~kJ}$ reported for $P$. carbinolicus $(4.1-4.3 \mathrm{~g} / \mathrm{mol}$ ethanol) growing on ethanol syntrophically with either $A$. woodii or Methanospirillum hungatei as partners (Schink 1984). The constant $Y_{\max }$ is probably the result of energetic homeostasis in the $\mathrm{H}_{2}$-producing $P$. acetylenicus exhibiting a constant $\triangle \mathrm{G}(-16.3 \mathrm{~kJ} / \mathrm{mol}$ ethanol $)$ at various growth rates and with different syntrophic partners (Seitz et al. 1990a).

The energy shared by Pelobacter was just sufficient for $0.32 \mathrm{~mol}$ reversible or $0.23 \mathrm{~mol}$ irreversible ATP synthesis per mol of ethanol oxidized (Thauer and Morris 1984; Schink 1990). ATP apparently is synthesized in these bacteria exclusively via acetate kinase (Schink 1984, 1985; Seitz et al. 1990b). A final explanation for synthesis of less than one ATP per fermentation reaction by substrate level phosphorylation is presently not available. It has been suggested that part of the ATP may be invested in acetate excretion (Schink 1991).

The Gibbs free energies of ethanol oxidation shared by the $\mathrm{H}_{2}$-oxidizing syntrophs strongly depended on the growth rate (Seitz et al. 1990a). At zero growth, the minimum energy ("critical" Gibbs free energy) required for homoacetogenesis, methanogenesis, and sulfate reduction was about $-20.4,-30.0$, and $-41.2 \mathrm{~kJ}$ per mol product, respectively (Seitz et al. 1990a). This energy allows irreversible synthesis of 0.3 to $0.6 \mathrm{~mol} \mathrm{ATP}$. The $\mathrm{H}_{2}$-oxidizing syntrophs are able to generate a proton motive force and probably use the resulting membrane potential to synthesize ATP in fractions of $1 / 3$ ATP per stoichiometric reaction (Thauer and Morris 1984). At high growth rates at which $\mathrm{Y}_{\max }$ is generated, the $\mathrm{H}_{2}$ oxidizing syntrophic partners apparently required more energy ( -55 to $-136 \mathrm{~kJ}$ per mol product; Table 3 ). This $(44-67 \%)$ of the total growth yield $(3.3-5.0 \mathrm{~g} / \mathrm{mol}$ ethanol). The total growth yields were comparable to those 
energy allows irreversible synthesis of 0.8 to $1.9 \mathrm{~mol}$ ATP.

Comparison of the individual $Y_{\max }$ with the individual Gibbs free energies available at high maximum rates allow the formal calculation of $\mathrm{Y}_{\Delta \mathrm{G}}$. $\mathrm{Y}_{\Delta \mathrm{G}}$ is comparable with $Y_{\text {ATP }}$ if ATP synthesis requires exactly $70 \mathrm{~kJ} / \mathrm{mol}$. The results indicate that both the ethanol-fermenting $\mathrm{H}_{2}$ producing $P$. acetylenicus and the $\mathrm{H}_{2}$-oxidizing homoacetogen $A$. woodii had a $Y_{\Delta \mathrm{G}}$ which agrees with the $\mathrm{Y}_{\text {ATP }}$ observed in other bacteria (Stouthamer 1979). The $\mathrm{H}_{2}$ oxidizing methanogenic $M$. bryantii and sulfate-reducing $D$. desulfuricans, on the other hand, exhibited a much lower $\mathrm{Y}_{\Delta \mathrm{G}}$. These differences may be due to various effects (for theoretical interpretation, compare Westerhoff et al. 1982; Van Dam et al. 1988):

(1) Efficiency of energy conversion may change with the bacterial species and the syntrophic status. E.g., $M$. bryantii and $D$. desulfuricans may produce less ATP than suggested from the available $\Delta \mathrm{G}$. Hence, they may uncouple ATP synthesis from substrate conversion, whereas $A$. woodii does not.

(2) The amount of energy required for ATP synthesis may be less than $70 \mathrm{~kJ} \mathrm{~mol}^{-1}$, e.g. if the ratio of ATP/ $\mathrm{ADP}$ is smaller than 10 (Schink 1990). In this case, $Y_{\Delta \mathrm{G}}$ calculated from $Y_{\max }$ and $\Delta \mathrm{G}$ values would be lower than expected in comparison with usual $\mathrm{Y}_{\mathrm{ATP}}$ values, e.g. in syntrophically grown $M$. bryantii and $D$. desulfuricans.

(3) ATP spillage reactions, e.g. ion leakage and energydependent transport, may be higher in syntrophically grown $M$. bryantii and $D$. desulfuricans than in $P$. acetylenicus and $A$. woodii.

(4) The energy demand for cell production in syntrophic coculture may be higher in $M$. bryantii and $D$. desulfuricans compared to P. acetylenicus and $A$. woodii.

Acknowledgements. We thank E. Kayser for technical assistance and the Deutsche Forschungsgemeinschaft and the Fonds der Chemischen Industrie for financial support.

\section{References}

Badziong W, Thauer RK (1978) Growth yields and growth rates of Desulfovibrio vulgaris (Marburg) growing on hydrogen plus sulfate and hydrogen plus thiosulfate as the sole energy source. Arch Microbiol 117:209-214

Cypionka H, Pfennig N (1986) Growth yields of Desulfotomaculum orientis with hydrogen in chemostat culture. Arch Microbiol $143: 396-399$

Fardeau ML, Belaich JP (1986) Energetics of the growth of Methanococcus thermolithotrophicus. Arch Microbiol 144: $381-385$
Lynd LH, Zeikus JG (1983) Metabolism of $\mathrm{H}_{2}-\mathrm{CO}_{2}$, methanol, and glucose by Butyribacterium methylotrophicum. J Bacteriol 153:1415-1423

Morrii H, Koga Y, Naga1 S (1987) Energetic analysis of the growth of Methanobrevibacter arboriphilus A2 in hydrogen-limited continuous cultures. Biotechnol Bioeng 29:310-315

Nethe-Jaenchen R, Thauer RK (1984) Growth yields and saturation constant of Desulfovibrio vulgaris in chemostat culture. Arch Microbiol 137:236-240

Pirt SJ (1965) The maintenance energy of bacteria in growing cultures. Proc R Soc 163 B:224-231

Roberton AM, Wolfe RS (1970) Adenosine triphosphate in Methanobacterium. J Bacteriol 102:43-51

Schink B (1984) Fermentation of 2,3-butanediol by Pelobacter carbinolicus sp.nov. and Pelobacter propionicus sp. nov., and evidence for propionate formation from $\mathrm{C}_{2}$ compounds. Arch Microbiol 137:33-41

Schink B (1985) Fermentation of acetylene by an obligate anaerobe, Pelobacter acetylenicus sp. nov. Arch Microbiol 142:295-301

Schink B (1990) Conservation of small amounts of energy in fermenting bacteria. In: Finn RK, Präve P (eds) Biotechnology focus 2. Hanser, München, pp 63-89

Schink B (1991) Syntrophism among prokaryotes. In: Balows A, Trüper HG, Dworkin M, Harder W, Schleifer KH (eds) The prokaryotes, 2nd edn. Springer, Berlin Heidelberg New York

Schönheit P, Moll J, Thauer RK (1980) Growth parameters (K, $\left.\mu_{\max }, Y_{s}\right)$ of Methanobacterium thermoautotrophicum. Arch Microbiol 127:59-65

Seitz HJ, Cypionka H (1986) Chemolithotrophic growth of Desulfovibrio desulfuricans with hydrogen coupled to ammonification of nitrate or nitrite. Arch Microbiol 146:63-67

Seltz HJ, Schink B, Pfennig N, Conrad R (1990a) Energetics of syntrophic ethanol oxidation in defined chemostat cocultures. 1. Energy requirement for $\mathrm{H}_{2}$ production and $\mathrm{H}_{2}$ oxidation. Arch Microbiol 155:82-88

Seitz HJ, Sineriz F, Schink B, Conrad R (1990b) Hydrogen production during fermentation of acetoin and acetylene by Pelobacter acetylenicus. FEMS Microbiol Lett 71:83-88

Stouthamer AG (1979) The search for correlation between theoretical and experimental growth yields. In: Quayle JR (ed) International review on biochemistry, microbiol biochemistry, vol 21. University Park Press, Baltimore, pp 1-47

Thauer RK, Morris JG (1984) Metabolism of chemotrophic anaerobes: old views and new aspects. Symp Soc Gen Microbiol $36: 123-168$

Thauer RK, Jungermann K, Decker K (1977) Energy conservation in chemotrophic anaerobic bacteria. Bacteriol Rev 41:100-180

Van Dam K, Mulder MM, De Mattos JT, Westerhoff HV (1988) A thermodynamic view of bacterial growth. In: Bazin MJ, Prosser JI (eds) Physiological modesl in microbiology, vol 1. CRC Press, Boca Raton, Florida, pp 25-48

Westerhoff HV, Lolkema JS, Otto R, Hellingwerf KJ (1982) Thermodynamics of growth. Non-equilibrium thermodynamics of bacterial growth. The phenomenological and the mosaic approach. Biochim Biophys Acta 683:181-220 